\title{
WBC count and functional changes induced by co-administration of clofazimine and clarithromycin, in single and multiple doses, in Wistar rats
}

\author{
Flávia Aparecida Paina ${ }^{1, *}$, Julise Cunha Miranda ${ }^{1}$, Cristiane Fernandes de Freitas Tavares ${ }^{1}$, \\ Regina Helena da Costa Queiroz ${ }^{1}$, Ana Maria de Souza ${ }^{1}$
}

${ }^{1}$ Departament of Clinical, Toxicological and Bromatological Analusis, Faculty of Pharmaceutical Sciences of Ribeirão Preto, Universidade de São Paulo

\begin{abstract}
Clofazimine and clarithromycin are used to treat leprosy and infections caused by Mycobacterium avium complex. Little data on the toxicity of co-administration of these two drugs are available. Here we evaluated the potential adverse effects of polytherapy with these two drugs in male Wistar rats by determining WBCs counts and other blood cell counts, neutrophilic phagocytosis, and burst oxidative, by flow cytometry. We observed an increase in WBCs, in multiple-dose regimens, and in polymorphonuclear cells, in both single- clarithromycin only and multiple dose regimens. We also observed a reduction in mononuclear cell counts in single and multiple doses. The drugs seem to reverse the mononuclear and polymorphonuclear cell ratio. An increase in oxidative burst was observed in animals treated with the drugs administered either individually or combined. In conclusion, clofazimine and clarithromycin change WBCs counts. Our results may contribute for a better understanding of the mechanisms related to the effects of co-administrating the two drugs.
\end{abstract}

Uniterms: Clofazimine/adverse effects/experimental study. Clarithromycin/adverse effects/experimental study. Leprosy/treatment. Mycobacterium avium/infections/treatment. Leukocytes. Phagocytosis. Oxidative burst.

\begin{abstract}
Clofazimina e laritromicina são utilizadas no tratamento da hanseníase e em infecções causadas pelo complexo Mycobacterium avium. Devido à escassez de dados sobre a toxicidade de esquemas terapêuticos que associam estes fármacos, este estudo teve por objetivo avaliar os efeitos adversos desta terapia, em ratos machos Wistar, por meio da determinação da contagem global e específica de leucócitos e ensaios de fagocitose e burst oxidativo de neutrófilos por citometria de fluxo. Houve aumento do número de leucócitos (dose múltipla) e de células polimorfonucleares (doses única e múltipla) nos grupos tratados com claritromicina em monoterapia ou associada à clofazimina e redução das células mononucleares, em doses única e múltipla, nos mesmos grupos. Os fármacos parecem inverter a proporção entre células mono e polimorfonucleares. Observou-se aumento do burst oxidativo nos animais tratados com os fármacos isolados ou associados. Concluindo, clofazimina e claritromicina provocam alterações leucocitárias e os resultados podem contribuir para melhor entendimento dos mecanismos relacionados aos efeitos da administração dos fármacos em associação.
\end{abstract}

Unitermos: Clofazimina/efeitos adversos/estudo experimental. Claritromicina/efeitos adversos/ estudo experimental. Hanseníase/tratamento. Mycobacterium avium/infecções/tratamento. Leucócitos. Fagocitose. Burst oxidativo.

\footnotetext{
*Correspondence: F. A. Paina. Universidade de Uberaba (Uniube). Av. Nenê Sabino 1801, sala 2D28 - Campus Aeroporto, Bairro Universitário - 38055-500 - Uberaba - MG, Brasil. Phone: +55 34 92261140. E-mail: 


\section{INTRODUCTION}

Clofazimine (CFZ) and clarithromycin (CRT) are antimicrobial drugs used for the treatment of diseases such as leprosy and tuberculosis, and for infections caused by the Mycobacterium avium complex in AIDS (acquired immune deficiency syndrome) patients (Ji et al., 1993; Field, Cowie, 2003; Katoch, 2004). Because these two drugs are used in polytherapy regimens it is important to investigate if their association results in adverse effects.

Established Mycobacterium avium infections are treated with a combination of clarithromycin and ethambutol, unless the isolate shows resistance to macrolides. Although the association between clarithromycin and ethambutol is the first choice for the treatment of disseminated infections, the alternatives include the use of azitromicin, ciprofloxacine, clofazimine, and amikacin. Co-administration of clofazimine and clarithromycin is effective and well-tolerated when used to treat infections caused by Mycobacterium avium.

Leprosy is a chronic infectious disease caused by Mycobacterium leprae. The disease is still current, especially in undeveloped and developing countries. The World Health Organization indicates the use of polychemotherapy for the treatment of Leprosy (Declercq, 2001). The treatment combines dapsone, clofazimine, and rifampicin. Clofazimine and clarithromycin have also shown to be effective (Chambers, 2007).

Although a number of studies have investigated the role of these two drugs over the modulation of inflammatory responses, including the production of reactive oxygen species (ROS) by phagocytes (Umeki, 1993; Lemke, 1995; Shirai et al., 1995; Wenisch et al., 1995; Wenisch et al., 1996; Abdelghaffar et al., 1997; Kadota et al., 1998; Kadir et al., 2000; Abdelghaffar et al., 2002; Jain et al., 2002; Sugihara et al., 2003; Tamaoki et al., 2004; Ishida et al., 2007; Yano et al., 2011), none have evaluated the effects of co-administration of the two drugs.

It is known that clofazimine stimulates the production of oxidants such as superoxide radical anion, which helps defend the organism against intracellular pathogens (Lemke, 1995; Yano et al., 2011). Macrolide antibiotics, including clarithromycin, act as immunomodulators in chronic inflammatory diseases of the respiratory tract by inhibiting the production of inflammatory cytokines. They also inhibit the mRNA of the transcription factors associated to these cytokines (Ishida et al., 2007). Additionally, due to its anti-inflammatory effects, clarithromycin blocks the formation of adhesion molecules necessary for the migration of the neutrophils to the body tissues (Tamaoki et al., 2004).
In a previous study (Paina et al., 2008) we observed a number of hematological, hemostatic, and biochemical changes in rats receiving monotherapy of either clofazimine or clarithromycin. However, no study has investigated the occurrence of potential changes when these two drugs are co-administered. In this study we investigated the effects that clofazimine and clarithromycin, either combined or separately, have over the number of leucocytes, mononuclear and polymorphonuclear cells and on the oxidative burst and neutrophilic phagocytosis in rats.

\section{MATHERIAL AND METHODS}

A total of 83 young Wistar SPF male rats (specific pathogen free) weighing between 240 and $260 \mathrm{~g}$ were provided by the Biotério II of the School of Pharmaceutical Sciences of University of São Paulo in Ribeirão Preto. The study here presented was approved by the Ethical Committee of the University of São Paulo (USP), Ribeirão Preto campus.

A total of 83 animals were separated in 8 groups as follows: the $\mathrm{CFZ}$-single group $(\mathrm{N}=7)$ was treated with a single dose of $100 \mathrm{mg}$ of clofazimine per $\mathrm{kg}$ of body weight; the CRT-single group $(\mathrm{N}=7)$ was treated with a single dose of $100 \mathrm{mg}$ of clarithromycin per $\mathrm{kg}$ of body weight; the CFZ + CRT-single group $(\mathrm{N}=7)$ was treated with a single dose of $100 \mathrm{mg}$ of each drug (clofazimine and clarithromycin) per kg of body weight. Blood collection was performed two hours after administration; the CFZ-multiple group $(\mathrm{N}=13)$ was treated with $100 \mathrm{mg}$ of clofazimine per $\mathrm{kg}$ of body weight every 12 hours for 4 days; the CRT-multiple group ( $\mathrm{N}=16)$ was treated with $100 \mathrm{mg}$ of clarithromycin per kg of body weight every 12 hours for 4 days; and the CFZ + CRT-multiple group $(\mathrm{N}=15)$ was treated with $100 \mathrm{mg}$ of each drug (clofazimine and clarithromycin) per kg of body weight every 12 hours for 4 days. Blood collection was conducted 12 hours after the last dose. Two control groups that received dimethylsufoxide (DMSO) in a single-dose regimen $(\mathrm{N}=7)$ or in a multiple-dose regimen $(\mathrm{N}=11)$ were also included in the study. The animals were euthanized by cervical dislocation after material collection.

\section{Reagents}

Phorbol myristate acetate (PMA) and $n$-formylmethionyl-leucyl-phenylalanine (fMLP) were obtained from the kit Burst Test (ORPEGEN Pharma, Heidelberg, Germany); dihydrorhodamine (DHR) and fluorescein isothiocyanate (FITC) were obtained from Sigma-Adrich (St. Louis, USA). 


\section{Methods}

- Manual WBC count was done using May-Grünwald/ Giemsa from total blood in EDTA, using optical microscope.

- Neutrophilic oxidative burst assay of peripheral blood, either or not stimulated by PMA or fMLP, was done according to the method described by Richardson et al. (1998): fluorescence intensity was measured by flow cytometry (FacScan ${ }^{\circledR}$, Becton-Dickinson, Bioscience, San Jose, USA). We worked with three different tubes containing $100 \mu \mathrm{L}$ of heparinized blood. To each tube we added one of the following: $25 \mu \mathrm{L}$ of PMA $8.1 \mu \mathrm{M}$, or $25 \mu \mathrm{L}$ of fMLP $8.1 \mu \mathrm{M}$, or $25 \mu \mathrm{L}$ of PBS. The blank control had $25 \mu \mathrm{L}$ of PBS only. All tubes were incubated at $37^{\circ} \mathrm{C}$ for 15 minutes. Next, $25 \mu$ L of DHR $30 \mu \mathrm{g} / \mathrm{mL}$ were added to both stimulated and unstimulated cells while $25 \mu \mathrm{L}$ of PBS were added to the white tube. The tubes were then incubated at $37^{\circ} \mathrm{C}$ for 5 minutes. Erythrocytes were lysed with $1 \mathrm{~mL}$ of lyse solution (BD FACSTM Lysing Solution, Becton Dickinson) for 10 minutes at room temperature. Next, we added $1 \mathrm{~mL}$ of PBS to the tubes. Cells were washed twice in PBS at a temperature between 4 and $8{ }^{\circ} \mathrm{C}, 400 \mathrm{~g}$, $5 \mathrm{~min}$, and resuspended with $1 \mathrm{~mL}$ of $1 \%$ paraformaldehyde in PBS. Reading was done with FACS, using argon-ion laser blue-green light at $488 \mathrm{~nm}$; 10,000 events were collected per sample.

- Neutrophilic phagocytosis assay: fluorescence intensity was measured by FACS (FacScan ${ }^{\circledR}$, Becton Dickinson, Bioscience, San Jose, USA). A total of $100 \mu \mathrm{L}$ of total heparinized blood was incubated with $100 \mu$ L of FITC-labeled Escherichia coli for 10 minutes at $37^{\circ} \mathrm{C}$. Addition of $100 \mu \mathrm{L}$ of quenching solution (trypan blue $4 \mathrm{mg} / \mathrm{mL}$ in $0.02 \mathrm{M}$ sodium citrate buffer) suppressed the florescence of non-phagocytized bacteria. Leucocytes were washed twice in PBS at $4-8^{\circ} \mathrm{C}$, centrifuged at $250 \mathrm{~g}$ for $5 \mathrm{~min}$, and erythrocytes were lysed with lysing solution (BD FACS ${ }^{\mathrm{TM}}$ Lysing Solution, Becton Dickinson) for 10 minutes at room temperature. Samples were once again washed at $4-8^{\circ} \mathrm{C}$, centrifuged at $250 \mathrm{~g}$ for $5 \mathrm{~min}$ and resuspended in $500 \mu \mathrm{L}$ of PBS and submitted to FACS argon-ion laser blue-green light at $488 \mathrm{~nm} ; 10,000$ events were collected per event.

\section{Statistical analysis}

We used the GraphPad Prism ${ }^{\circledR}$ program version 5.0 for the non-parametric Kruskal-Wallis test followed by the Dunns post-test and ANOVA followed by Bonferroni post-test. Significant levels were set as $p<0.05$.

\section{RESULTS}

\section{Effects of clofazimine and clarithromycin, combined and separated, over the number of leucocytes, mononuclear cells, and polymorphonuclear cells of the peripheral blood}

WBC counts in rats treated with the drugs and with the control (DMSO) in single-dose regimens presented no statistical difference among groups (data not shown). For multiple-doses regimens, animals treated with clarithromycin and with co-administration of the two drugs showed an increased number of WBCs when compared to the control group (Figure 1A).

Figure $1 \mathrm{~B}$ and $1 \mathrm{C}$ shows the number of mononuclear cells in rats treated with single- and multiple-dose regimens. We observed a reduction in cell counts in animals treated with clarithromycin and with co-administration of the two drugs, when compared to the control group and to the group treated with clofazimine only, either in single-dose regimens or in multiple doses. Although no statistical difference was observed among the groups receiving single doses, as indicated by the Dunns post-test, the difference could be seen through the median of the samples $(\mathrm{p}<0.05)$.

There was an increase in polymorphonuclear cell counts in all cases, when compared to controls (Figure $1 \mathrm{D}$ and $1 \mathrm{E})$.

\section{Effects of clofazimine and clarithromycin, combined and separated, over oxidative burst and neutrophilic phagocytosis}

In multiple-dose regimens the oxidative burst was more characterized in the groups stimulated with PMA when compared to those non-stimulated or stimulated with fMLP. Additionally, animals treated with CFZ + CRT showed a higher oxidative burst activity when compared to controls or to animals treated with one drug only $(\mathrm{p}<0.0001)$ (Figure 1F). No statistical difference was observed among groups for the neutrophilic phagocytosis (data not shown).

\section{DISCUSSION}

Studies on drug effects are important for optimization of therapies so patients can receive treatments that are more effective and safer. The choice of the drugs dose 

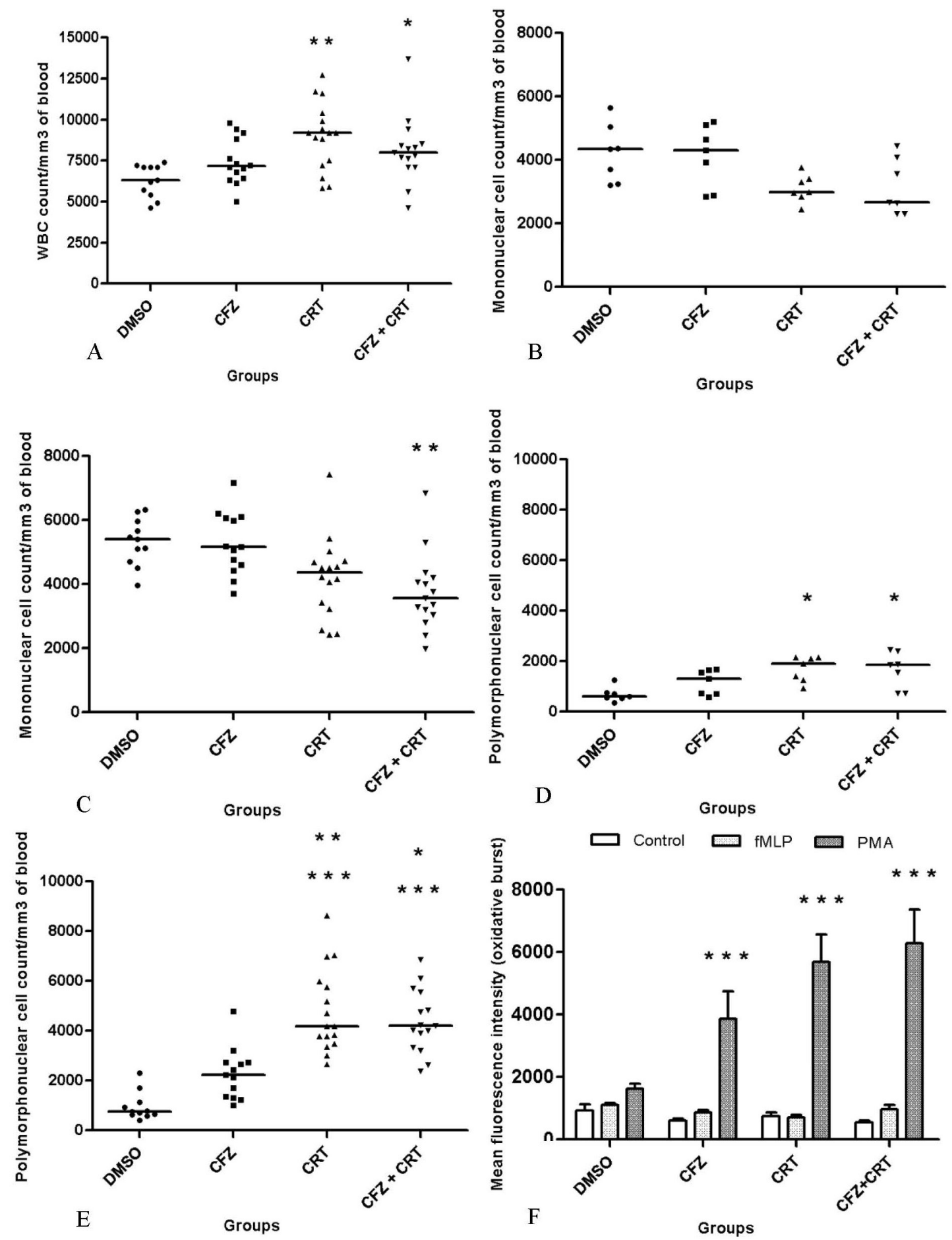

FIGURE 1 - Quantitative and functional rats WBC treated with clofazimine (CFZ), clarithromycin (CRT) and the combination of the two drugs at a dose of $100 \mathrm{mg} / \mathrm{kg}$, compared with the control DMSO. A: WBC counts in multiple dose regime (KruskalWallis test followed by Dunns multiple comparison, ${ }^{*} \mathrm{p}<0.05$ and ${ }^{* *} \mathrm{p}<0.001$ compared to DMSO), B: Mononuclear cell count in single-dose regimen (Kruskal-Wallis, $\mathrm{p}<0.05$ ), C: Number of mononuclear cells in multiple-dose regimen (Kruskal-Wallis test followed by Dunns multiple comparisons, ${ }^{* *} \mathrm{p}<0.001$ For DMSO and CFZ), D: Polymorphonuclear cell counts in single-dose regimen (Kruskal-Wallis test followed by Dunns multiple comparison, ${ }^{*} \mathrm{p}<0.05$ for DMSO), E: Polymorphonuclear cell counts under multiple-dose regimens (Kruskal-Wallis test followed by Dunns multiple comparisons, $* * p<0.001$ compared to CFZ, *** $\mathrm{p}<0.0001$ compared to DMSO, $* \mathrm{p}<0.05$ for CFZ, $* * * \mathrm{p}<0.0001$ compared to DMSO), F: Mean fluorescence intensity produced by the oxidative burst of neutrophils in multiple-dose regimen (ANOVA test. CFZ: *** $p<0.001$ compared to control and fMLP; CRT: *** $p<0.001$ compared to control and fMLP; CFZ + CRT: *** $p<0.001$ compared to control and fMLP). 
used in this work was based on the highest dose used for human treatment.

We observed that CRT-multiple, as well as CFZ+CRT-multiple, increased WBC counts. Although no statistical significance was observed, CFZ-multiple presented higher median values when compared to the DMSO control group (not shown). Interesting, among the adverse effects associated to erythromycin, which is a structural analogue of clarithromycin, are leukocytosis and eosinophilia. Nevertheless, it has been reported that all adverse effects disappear within a few days after the treatment is over (Chambers, 2007).

A reduction of mononuclear count was observed in rats receiving CRT-single or CFZ + CRT-single. Although the Dunn's post-test revealed no statistical difference among groups, differences in the median values $(p<0.05)$ were observed when the Kruskal-Wallis test was applied (Figure 1B). Mononuclear cell count was also reduced in both CRT-multiple and CFZ + CRT-multiple, but a significant reduction was observed only when the two drugs were combined (CFZ + CRT-multiple) (Figure 1C). Polymorphonuclear cells presented opposite behaviors in treated groups when compared to control. In this case an augmentation in cell counts in the CFZ, CRT, and CFZ+CRT groups in both regimens was observed (Figure $1 \mathrm{D}$ and $1 \mathrm{E})$. We noticed a reduction in mononuclear cell counts and an increase in polymorphonuclear cell counts only in the CRT and CFZ+CRT groups, indicating that CRT is the drug responsible for inverting the cell ratio. This may be due to a mobilization of the marginal neutrophilic pool, as the time-lapse between drug (or control) injections and sample collection was of two hours only. This effect was more pronounced in multi-dose regimens. In this case, the mechanism may be related to the drug's antimicrobial and anti-inflammatory actions, which also affect the neutrophilic functional response.

Previous studies have reported a reduction in lymphocyte counts in the broncho-alveolar wash of patients of chronic respiratory diseases who used macrolides for long periods. The effects of macrolides over human lymphocytes isolated from peripheral blood are also associated with apoptosis induction, which may be related to the anti-inflammatory actions of clarithromycin, azitromicin, and josamicin (Ishimatsu et al., 2004). It has also been shown that clarithromycin may reduce lymphocyte counts in the lungs of rats with respiratory infection caused by Pseudomonas aeruginosa (Mukae et al., 1995). Similar results were observed in studies on lung diseases in humans (Yanagihara et al., 1997).

The oxidative burst analysis in rats' neutrophils treated with multiple-dose regimens (Figure 1F), revealed an increase of activity in all groups, regardless of the number of drugs used (whether one drug or the two drugs combined) when stimulated with PMA, as compared to those stimulated with fMLP. This may be explained by the fact that a few receptors for AMLP are available on neutrophils (Vuorte et al., 1996). Additionally, PMA is a structural analog of the diacylglicerol and a potent and lipophilic stimulant that crosses the cell membrane with ease where it activates the oxidative burst through the kinase $\mathrm{C}$ protein (PKC) (Sheppard et al., 2005). The increase in oxidative bust activity followed the CFZ $<\mathrm{CRT}<\mathrm{CFZ}+\mathrm{CRT}$ order.

In this study we observed an increase in oxidative burst in rats' neutrophils treated with clofazimine in multidose regimen, which agrees with previous studies showing the occurrence of ROS as a mechanism of antimicrobial action and protection against infections (Lemke, 1995; Yano et al., 2011). However, it has been shown that macrolides inhibit production of neutrophilic ROS (Umeki, 1993; Abdelghaffar et al., 1997; Kadota et al., 1998; Kadir et al., 2000; Abdelghaffar et al., 2002; Jain et al., 2002; Sugihara et al., 2003). This apparent disparity in findings may be explained by the fact that in our study the neutrophilic oxidative burst analysis was done in ex-vivo and with total blood, whereas in previous studies this analysis was done in vitro (Umeki, 1993; Abdelghaffar et al., 1997; Kadota et al., 1998; Kadir et al., 2000; Abdelghaffar et al., 2002; Jain et al., 2002; Sugihara et al., 2003). It has been suggested that difficulties associated to cell isolation may affect the results because when the phagocyte is isolated from the total blood any factor necessary for its modulation may be missing (Labro, 2000). By using total blood we avoided separating the granulocytes and precluded the cellular activation that may occur due to the separation. Also to be considered are the different functional capacities of several pools of granulocytes and monocytes/ macrophages. Finally, the use of ex-vivo models allows better accuracy and reproducibility (Wenisch et al., 1996).

Studies reporting inhibition of neutrophilic oxidative burst by macrolides (Umeki, 1993; Abdelghaffar et al., 1997; Kadota et al., 1998; Kadir et al., 2000; Abdelghaffar et al., 2002; Jain et al., 2002; Sugihara et al., 2003) used techniques like cytochrome-c reduction or chemiluminescence of luminol and lucigenin, which evaluate ROS release in the extracellular environment. FACS evaluates intracellular ROS. Of note is the fact that the dihydrorhodamine 123 (DHR) used to detect ROS binds to cellular and mitochondrial membranes, thus it detects an intracellular signal that responds to the presence of $\mathrm{H}_{2} \mathrm{O}_{2}$, specifically (Elbim, Lizard, 2009).

In studies that used FACS to evaluate the effects of antimicrobial treatments on neutrophilic burst oxidative 
activity and phagocytosis (Wenisch et al., 1995; Wenisch et al., 1996), no changes in ROS production were observed in patients who used clarithromycin. In a different study, an increase in neutrophilic oxidative burst activity was observed (Shirai et al., 1995). Methods using chemiluminesence and others that use nitroblue tetrazolium (NBT) reduction show great intra and inter variation and are considered of low accuracy (Wenisch et al., 1996).

Another difference between in vitro and ex-vivo analysis regards the plasmatic and/or intracellular concentration of the macrolides and the phagocytosis capacity of polymorphonuclear cells and ROS production. In the studies mentioned earlier, authors (Umeki, 1993; Abdelghaffar et al., 1997; Kadota et al., 1998; Kadir et al., 2000; Abdelghaffar et al., 2002; Jain et al., 2002; Sugihara et al., 2003) could control the concentration of the drug responsible for inhibiting ROS production by neutrophils, as the drugs were directly incubated with the cells. It is known that the level of intracellular concentration does not necessarily relate with the intracellular drug activity and that the drug penetration and intracellular localization should also be considered (Wenisch et al., 1996).

Several factors affect antibiotics activity in vivo. The applied dose may affect the susceptibility of the infectious agent, and the concentration it reaches in the plasma and in other body fluids and tissues. Most important is the concentration it reaches in the infection site (Bakker-Woudenberg et al., 2005). Indeed, a previous report revealed that the increase or reduction of drug concentration in phagocytes is directly proportional to plasma concentrations (Amsden, 2001). This work also points out that in vitro susceptibility studies do not reflect the actual antibiotic concentrations to which he pathogen is exposed at the infection site, where it is phagocytosed by the immune system. Another problem of in vitro minimum inhibitory concentration determinations is that such tests do not consider the inherent activity of the plasma, which can cause changes in the final concentration values.

Another issue on the different findings between ex-vivo and in vitro studies regards the mononuclear and polymorphonuclear cell ratio. The increased number of polymorphonuclear leukocytes may explain the increased neutrophils-mediated oxidative burst. All the aforementioned issues may be related to controversial data previously reported regarding the effects of clarithromycin on neutrophilic oxidative burst (Umeki, 1993; Abdelghaffar et al., 1997; Kadota et al., 1998; Kadir et al., 2000; Abdelghaffar et al., 2002; Jain et al., 2002; Sugihara et al., 2003).

Cytokine secretions such as interleukins, growth factors, interferons, and tumor necrosis factor, are made by leukocytes and other cell types. They provide both stimulation and inhibition of hematopoiesis (Socolovsky, 1998) and are important mediators of inflammation. Macrolide antibiotics exert anti-inflammatory effects by inhibiting the production of these cytokines through the modulation of the nuclear factor $\mathrm{kB}$ (NF-kB), a transcription factor for genes that encode pro-inflammatory cytokines such as IL1, IL-6, IL-8, and TNF- $\alpha$. Additionally, these antibiotics also inhibit the production of prostaglandin E2, and neutrophil chemotaxis and elastase activity. Clarithromycin modulates the proliferation of antigen-specific $\mathrm{T}$ cells and enhances the anti-M. avium activity mediated by IL-12 (Ichiyama et al., 2001).

Clarithromycin affects cytokine production by dendritic cells and T cells by inhibiting IL-2 and IL-6 production, suppressing $\mathrm{B}$ cell activation and improving the condition of patients with lung disease (Sugiyama et al., 2007). Furthermore, it increases production of IL-10, which inhibits the production of pro-inflammatory cytokines such as IL-2, IL-8, and TNF- $\alpha$. Similarly, Mukae et al. (2010) found that Pseudomomas aeruginosa infections change the functions of dendritic cells and that macrolides act as anti-inflammatory agents modulating the functions of these cells by reducing the production of IL-6, IL-12, and TNF- $\alpha$.

Reduction of neutrophils in the patients' airways also decreased the release of leukotriene B4 and granule enzymes such as $\beta$-glucuronidase, lysozyme, and hydrolase. It also resulted in ROS production, which can cause tissue injury (Diep et al., 2010). Thus, macrolides decrease the number of airway infections not only by their direct effects on bacteria, but also by their ability to reduce inflammation (Yanagihara et al., 1997).

Therefore, the macrolides' antimicrobial activity added to their involvement with cytokine production and release may affect regulation of hematopoiesis. Indeed, hematopoiesis is mediated by a range of cytokines that promote changes in the production and release of blood cells from the bone marrow to the peripheral blood and hence to the tissues. The process depends on drug plasma concentration and dose regimen, which in turn affect the time course of drug action.

No statistical difference between phagocytosis in control cells and in rat cells treated with the drugs was observed. The literature is controversial regarding the action of clarithromycin on the neutrophilic phagocytosis. While a report observed a decreased phagocytosis associated to the drug (Wenisch et al., 1996), other studies reported an increased activity (Roszkowski et al., 1990; Scaglione et al., 1993; Xu et al., 1995). Differences in methodology, the animal and human models used, the concentrations 
of the drug in vivo and in vitro, the protocols, and dosage and administration may partially explain the differences reported by these studies (Labro, 2000). Before our study, no results on the effects of the two drugs (clarithromycin and clofazimine) over neutrophilic phagocytosis were available.

Our study provides some initial results on the effects that the use of these two drugs combined may have on the oxidative burst and on neutrophilic phagocytosis. Nevertheless we cannot say that these same results would be observed in patients taking these drugs. It is possible that different results could be found due to differences in the immune response while in an inflammatory environment, which might be observed in studies done with disease models.

Because a combination of the two drugs has been indicated for the treatment of Leprosy (Declercq, 2001) and for the treatment of the infections caused by the Mycobacterium avim complex (Field, Cowie, 2003), its important to know how these two drugs act and what kind of side effects they may have. Our data may contribute to a better understanding of the effects of these two drugs when used to treat these diseases.

\section{ACKNOWLEDGMENTS}

To Fabiana Rosseto de Morais, Jenniffer Michiko Chauca Yokoya, Joseane Cristina Ferreira, Zelma Fernandes and Zita Maria de Oliveira Gregório for technical support. Funding: CNPq

\section{REFERENCES}

ABDELGHAFFAR, H.; VAZIFEH, D.; LABRO, M.T. Erythromycin A-derived macrolides modify the functional activities of human neutrophils by altering the phospholipase D-phosphatidate phosphohydrolase transduction pathway: L-cladinose is involved both in alterations of neutrophil functions and modulation of this transductional pathway. J. Immunol., v.159, p.3995-4005, 1997.

ABDELGHAFFAR, H.; KIRST, H.; SOUKRI, A.; BABIN-CHEVAVE, C.; LABRO, M.T. Structureactivity relationships among $9-\mathrm{N}$-alkyl derivatives of erythromycylamine and their effect on the oxidative burst of human neutrophils in vitro. J. Chemother., v.14, p.132$139,2002$.

AMSDEN, G.W. Advanced-generation macrolides: tissuedirected antibiotics. Int. J. Antimicrob. Agents., v.18, suppl. 1, p.11-15, 2001.
BAKKER-WOUDENBERG, I.A.J.M.; VIANEN, W.V.; SOOLINGEN, D.V.; VERBRUGH, H.A.; AGTMAEL, M.A.V. Antimycobacterial agents differ with respect to their bacteriostatic versus bactericidal activities in relation to time of exposure, mycobacterial growth phase, and their use in combination. Antimicrob. Agents Chemother., v.49, p.2387-2398, 2005.

CHAMBERS, H.F. Inibidores da síntese de proteínas e agentes antibacterianos diversos. In: BRUNTO, L.L.; LAZO, J.S.; PARKER, K.L. Goodman \& Gilman, As bases farmacológicas da terapêutica. 11.ed. Rio de Janeiro: McGraw-Hill, 2007. p.1055-1082.

DECLERCQ, E. "Guide to eliminate leprosy as a public health problem" (first edition, 2000, World Health Organization). Int. J. Lepr. Other Mycobact. Dis., v.69, p.34-35., 2001.

DIEP, B.A.; CHAN, L.; TATTEVIN, P.; KAJIKAWA, O.; MARTIN, T.R.; BASUINO, L.; MAI, T.T.; MARBACH, H.; BRAUGHTON, K.R.; WHITNEY, A.R.; GARDER, D.J.; FAN, X.; TSENG, C.W.; LIU, G.Y.; BADIOU, C.; ETIENNE, J.; LINA, G.; MATTHAY, M.A.; DeLEO, F.R.; CHAMBERS, H.F. Polymorphonuclear leukocytes mediate Staphylococcus aureus Panton-Valentine leukocidininduced lung inflammation and injury. Proc. Natl. Acad. Sci. USA., v.107, p.5587-5592, 2010.

ELBIM, C.; LIZARD, G. Flow cytometric investigation of neutrophil oxidative burst and apoptosis in physiological and pathological situations. Cytometry A., v.75, p.475-481, 2009.

FIELD, S.K.; COWIE, R.L. Treatment of Mycobacterium avium-intracellulare complex lung disease with a macrolide, ethambutol, and clofazimine. Chest., v.124, p.1482-1486, 2003.

ISHIDA, Y.; ABE, Y.; HARABUCHI, Y. Effects of macrolides on antigen presentation and cytokine production by dendritic cells and T lymphocytes. Int. J. Pediatr. Otorhinolaryngol., v.71, p.297-305, 2007.

ISHIMATSU, Y.; KADOTA, J.; IWASHITA, T.; NAGATA, T.; ISHII, H.; SHIKUWA, C.; KAIDA, H.; MUKAE, H.; KOHNO, S. Macrolide antibiotics induce apoptosis of human peripheral lymphocytes in vitro. Int. J. Antimicrob. Agents., v.24, p.247-253, 2004. 
ICHIYAMA, T.; NISHIKAWA, M.; YOSHITOMI, T.; HASEGAWA, S.; MATSUBARA, T.; HAYASHI, T.; FURUKAWA, S. Clarithromycin inhibits NF-kB activation in human peripheral blood mononuclear cells and pulmonary epithelial cells. Antimicrob. Agents Chemoter., v.45, p.44-47, 2001.

JAIN, A.; SANGAL, L.; BASAL, E.; KAUSHAL, G.P.; AGARWAL, S.K. Anti-inflammatory effects of erythromycin and tetracycline on Propionibacterium acnes induced production of chemotactic factors and reactive oxygen species by human neutrophils. Dermatol. Online J., v.8, p.2, 2002.

JI, B.; JAMET, P.; PERANI, E.G.; BOBIN, P.; GROSSET, J.H. Powerful bactericidal activities of clarithromycin and minocycline against Mycobacterium leprae in lepromatous leprosy. J. Infect. Dis., v.168, p.188-190, 1993.

KADIR, T.; IZZETIN, F.V.; CEVIKBAS, A.; JOHANSSON, C.B.; CLARK, P. In vitro effects of clarithromycin on human polymorphonuclear leukocyte functions. Chemotherapy., v.46, p.198-203, 2000.

KADOTA, J.; IWASHITA, T.; MATSUBARA, Y.; ISHIMATSU, Y.; YOSHINAGA, M.; ABE, K.; KOHNO, S. Inhibitory effect of erythromycin on superoxide anion production by human neutrophils primed with granulocyte-colony stimulating factor. Antimicrob. Agents Chemother., v.42, p.1866-1867, 1998.

KATOCH, V.M. Infections due to non-tuberculous mycobacteria (NTM). Indian J. Med. Res., v.120, p.290-304, 2004.

LABRO, M.T. Interference of antibacterial agents with phagocyte functions: immunomodulation or "immuno-fairy tales"? Clin. Microbiol. Rev., v.13, p.615-650, 2000.

LEMKE, T.L. Antimycobacterial Agents. In: FOYE, W.O.; LEMKE, T.L.; WILLIAMS, D.A. Principles of medicinal chemistry. 4.ed. Philadelphia: Lippincott Williams \& Wilkins, 1995. p.756-757.

MUKAE, H.; KADOTA, J.; KOHNO, S.; KUSANO, S.; MORIKAWA, T.; MATSUKURA, S.; HARA, K. Increase in activated CD8+ cells in bronchoalveolar lavage fluid in patients with diffuse panbronchiolitis. Am. J. Respir. Crit. Care Med., v.152, p.613-618, 1995.
MUKAE, H.; URABE, K.; YANAGIHARA, K.; ISHIMOTO, H.; SAKAMOTO, N.; ISHII, H.; NAKAYAMA, S.; ISHIMATSU, Y.; ABE, K.; SHIRAI, R.; KOHNO, S. Low expression of T-cell co-stimulatory molecules in bone marrow-derived dendritic cells in a mouse model of chronic respiratory infection with Pseudomonas aeruginosa. Tohoku J. Exp. Med., v.220, p.59-65, 2010.

PAINA, F.A.; QUEIROZ, R.H.; SOUZA, A.M. Hematological, hemostatic and biochemical alterations induced by clofazimine and clarithromycin, in single and multiple doses, in rats. Rev. Soc. Bras. Med. Trop., v.41, p.282-287, 2008.

RICHARDSON, M.P.; AYLIFFE, M.J.; HELBERT, M.; DAVIES, E.G. A simple flow cytometry assay using dihydrorhodamine for the measurement of the neutrophil respiratory burst in whole blood: comparison with the quantitative nitrobluetetrazolium test. J. Immunol. Methods., v.219, p.187-193, 1998.

ROSZKOWSKI, K.; BEUTH, J.; KO, H.L.; PETERS, G.; PULVERER, G. Comparative study on the macrolides erythromycin and clarithromycin: antibacterial activity and influence on immune responses. Zentralbl. Bakteriol., v.273, p.518-530, 1990 .

SCAGLIONE, F.; FERRARA, F.; DUGNANI, S.; DEMARTINI, G.; TRISCARI, F.; FRASCHINI, F. Immunostimulation by clarithromycin in healthy volunteers and chronic bronchitis patients. J. Chemother., v.5, p.228-232, 1993.

SHEPPARD, R.F.; KELHER, M.R.; MOORE, E.E.; NATHAN, J.D.; MCLAUGHLIN, N.J.D.; BANERJEE, A.; SILLIMAN, C.C. Structural organization of the neutrophil NADPH oxidase: phosphorylation and translocation during priming and activation. J. Leukoc. Biol., v.78, p.1025-1042, 2005.

SHIRAI, T.; SATO, A.; CHIDA, K. Effect of 14-membered ring macrolide therapy on chronic respiratory tract infections and polymorphonuclear leukocyte activity. Intern. Med., v.34, p.469-474, 1995.

SOCOLOVSKY, M.; CONSTANTINESCU, S.N.; BERGELSON, S.; SIROTKIN, A.; LODISH, H.F. Cytokines in hematopoiesis: specificity and redundancy in receptor function. Adv. Protein. Chem., v.52, p.141-198, 1998. 
SUGIHARA, E.; KOYANAGI, T.; NIZEKI, T.; HIROTA, N.; NAGAFUCHI, M.; YAMADA, K.; KIDO, Y.; ONO, N.; RIKIMARU, T.; AIZAWA, H. Macrolide antibiotics directly reduce active oxygen generation by neutrophils in human peripheral blood. Kurume Med. J., v.50, p.9-15, 2003.

SUGIYAMA, K.; SHIRAI, R.; MUKAE, H.; ISHIMOTO, H.; NAGATA, T.; SAKAMOTO, N.; ISHII, H.; NAKAYAMA, S.; YANAGIHARA, K.; MIZUTA, Y.; KOHNO, S. Differing effects of clarithromycin and azithromycin on cytokine production by murine dendritic cells. Clin. Exp. Immunol., v.147, p.540-546, 2007.

TAMAOKI, J.; KADOTA, J.; TAKIZAWA, H. Clinical implications of the immunomodulatory effects of macrolides. Am. J. Med., v.117, p.5S-11S, 2004.

UMEKI, S. Anti-inflammatory action of erythromycin. Its inhibitory effect on neutrophil NADPH oxidase activity. Chest., v.104, p.1191-1193, 1993.

VUORTE, J.; JANSSON, S.E.; REPO, H. Standardization of a flow cytometric assay for phagocyte respiratory burst activity. Scand. J. Immunol., v.43, p.329-334, 1996.

WENISCH, C.; PARSCHALK, B.; HASENHÜNDL, M.; WIESINGER, E.; GRANINGER, W. Effect of cefodizime and ceftriaxone on phagocytic function in patients with severe infections. Antimicrob. Agents Chemother., v.39, p.672-676, 1995.
WENISCH, C.; PARSCHALK, B .; ZEDT WITZLIEBENSTEIN, K.; WEIHS, A.; El-MENYAWI, I.; GRANINGER, W. Effect of single oral dose of azithromycin, clarithromycin, and roxithromycin on polymorphonuclear leukocyte function assessed ex vivo by flow cytometry. Antimicrob. Agents Chemother., v.40, p.2039-2042, 1996.

XU, G.; FUJITA, J.; NEGAYAMA, K.; OHNISHI, T.; MIYAWAKI, H.; HOIO, S.; TAKIGAWA, K.; OKADA, H.; YAMAII, Y.; TAKAHARA, J. Effect of clarithromycin on macrophage functions. Kansenshogaku Zasshi., v.69, p.864-872, 1995.

YANAGIHARA, K.; TOMONO, K.; SAWAI, T.; HIRAKATA, Y.; KADOTA, J.; KOGA, H.; TASHIRO, T.; KOHNO, $\mathrm{S}$. Effect of clarithromycin on lymphocytes in chronic respiratory Pseudomonas aeruginosa infection. Am. J. Respir. Crit. Care Med., v.155, p.337-342, 1997.

YANO, T.; KASSOVSKA-BRATINOVA, S.; TEH, J.S.; WINKLER, J.; SULLIVAN, K.; ISAACS, A.; SCHECHTER, N.M.; RUBIN, H. Reduction of clofazimine by mycobacterial type 2 NADH:Quinone oxidoreductase: A pathway for the generation of bactericidal levels of reactive oxygen species. J. Biol. Chem., v.286, p.10276$10287,2011$.

Received for publication on $09^{\text {th }}$ March 2012 Accepted for publication on $13^{\text {th }}$ July 2012 
